\title{
Turtle-associated salmonellosis due to Salmonella Litchfield in a 57-day-old infant: a case report
}

\author{
Hisao Okabe ${ }^{1}$, Hiromichi Murai ${ }^{1}$, Shunya Takano ${ }^{1}$, and Shuto Kanno ${ }^{1}$ \\ ${ }^{1}$ Shirakawa Kosei General Hospital, Japan
}

\begin{abstract}
A 57-day-old boy presented with fever, watery diarrhea, and anorexia and was admitted with suspected acute gastroenteritis. His laboratory data suggested low-level inflammation and cholestasis. His stool culture was positive for Salmonella Litchfield. With suspicion of bacterial infection, the patient received intravenous ampicillin for 5 days. On the fifth day after admission, his inflammatory and cholestasis markers normalized, and he was discharged from the hospital in good condition. His family kept five Japanese pond turtles as pets for one year. As Salmonella Litchfield was isolated from a swab sample of the turtle's body. The patient was diagnosed with turtle-associated salmonellosis. In conclusion, families, particularly those with infants, should avoid keeping turtles in their homes. Pet shop owners and public health authorities must provide appropriate information regarding Salmonella in turtles.
\end{abstract}

Key words: turtle-associated salmonellosis, infant, Salmonella Litchfield, Salmonella enterica, Japanese pond turtle

\section{Introduction}

Salmonellosis is frequently associated with the ingestion of contaminated foods of animal origin or contact with animals such as turtles and other reptiles, which are major reservoirs of Salmonella ${ }^{1}$. The number of pet reptiles has increased worldwide ${ }^{2,3)}$. Salmonella Litchfield, a serotype of Salmonella enterica subsp. enterica, is occasionally isolated from turtles ${ }^{4)}$.

To our knowledge, this is the first report from Japan of turtle-associated salmonellosis (TAS) in an infant younger than 2 months of age and the first report of salmonellosis associated with Japanese pond turtles.

\section{Case Report}

A 57-day-old boy presented to the hospital after expe-

Received: February 18, 2021

Accepted: May 31, 2021

Correspondence: Hisao Okabe, Shirakawa Kosei General Hospital, 2-1 Toyochikamiyajirou, Shirakawa-City, Fukushima 961-005, Japan E-mail: 1988hisao@gmail.com

This is an open-access article distributed under the terms of the Creative Commons Attribution Non-Commercial No Derivatives
(by-nc-nd) License $<\mathrm{http} / / /$ creativecommons.org/ licenses/by-nc-nd/4.0/> riencing fever and diarrhea for 2 days. The patient experienced fever $\left(39.0^{\circ} \mathrm{C}\right)$, watery diarrhea (15 times a day), and anorexia. His stools were initially pale yellow and were later green, with and laced with some blood. He had no history of vomiting or respiratory symptoms. He was admitted with suspected acute gastroenteritis.

The patient was born at 34 weeks and 3 days of gestation, with a birth weight of 2,040 g. He was discharged from the hospital at a modified gestational age of 37 weeks and 20 days. He was breastfed.

On physical examination, the patient showed tachycardia of 190 beats per minute, no murmurs, $100 \% \mathrm{O}_{2}$ saturation, and stable breathing and circulation. His laboratory data included a white blood cell count of $3,800 / \mu \mathrm{L}$ and $\mathrm{C}$ reactive protein level of $2.06 \mathrm{mg} / \mathrm{dL}$ suggestive of low-level inflammation, a total bilirubin level of $4.06 \mathrm{mg} / \mathrm{dL}$, a direct bilirubin level of $1.14 \mathrm{mg} / \mathrm{dL}$, and an alkaline phosphatase level of 1,961 IU/L suggestive of cholestasis. Microbiological investigations including blood and urine cultures were negative, while a stool culture was positive for Salmonella Litchfield susceptible to ampicillin, ceftriaxone, and levofloxacin and resistant to cefazolin, cefmetazole, amikacin, and gentamicin.

With the suspicion of a bacterial infection, he received intravenous ampicillin for 5 days. On the third day after admission, his temperature returned to normal, and his diarrhea and anorexia improved. On the fourth day after ad- 
mission, Salmonella Litchfield was isolated from the fecal specimens collected at the time of admission, and he was diagnosed with salmonellosis. On the fifth day after admission, his inflammatory and cholestasis markers normalized and he was discharged from the hospital in good condition. However, his stool culture was still positive for Salmonella Litchfield 6 months after discharge.

The patient's family reported that they had been keeping five Japanese pond turtles as pets at their home for 1 year. The patient's father usually handled the turtles, while the other family members did not. The aquarium and related materials were routinely washed in the bathroom. As Salmonella Litchfield was isolated from a swab sample of the turtle's body, the patient was diagnosed with TAS. Salmonella was not isolated from the bathroom swab samples.

The patient's parents provided consent for the publication of this case report.

\section{Discussion}

Salmonellosis is a symptomatic infection caused by Salmonella enterica, which is classified into six subspecies. One of them, S. enterica subsp. enterica, constitutes the majority (99.5\%) of isolates cultured from humans and other warm-blooded animals and contains the majority of disease-causing serovars ${ }^{5}$. Salmonella Litchfield is a major serotype of $S$. enterica subsp. enterica, which is occasionally isolated from turtles ${ }^{4}$. Outbreaks of Salmonella Litchfield have been reported in the United States, Europe, and Australia $^{6-9)}$, while two cases of TAS due to Salmonella Litchfield have been reported in Japan ${ }^{10,11)}$.

Infants and young children are more likely than the general population to become infected with Salmonella and are at greater risk of developing its complications, such as septicemia, meningitis, and death ${ }^{12)}$. Further, infants and young children also at an increased risk of developing TAS ${ }^{13)}$. To prevent TAS among children, the United States Food and Drug Administration enacted a ban prohibiting the sale and distribution of turtles with a shell length of $<4$ inches within the United States in 1975. The federal ban was effective, preventing an estimated 100,000 cases of TAS in children annually after its enactment ${ }^{14}$. Similar regulations prohibiting small turtles in Sweden also reduced their incidence of turtle-associated Salmonella infections ${ }^{15)}$. In addition to regulations, a public health education campaign providing appropriate information to the public about the risk of TAS also helped to decrease the number of cases of TAS.

Two cases of salmonellosis in children associated with red-eared sliders were first reported in Japan in 1975'16). As subsequent reports of TAS arose, pet turtles were identified as a source of salmonellosis in Japan as well as other countries. Since then, several cases of TAS have been reported in Japan $^{17-19)}$. The recommendations provided by the Ministry of Health, Labour and Welfare of Japan include: (i) wash hands thoroughly with soap and water after handling turtles, (ii) avoid keeping turtles at homes where children, elderly individuals, or individuals with weakened immune systems live; (iii) prevent turtles from roaming freely in homes, living areas, and food preparation areas; and (iv) avoid washing turtle enclosures and supplies in kitchen sinks ${ }^{20}$.

The Japanese pond turtle is a species of turtle in the family Geoemydidae distributed in Japan that is a popular pet in Japan. Although Kameyama M et al. reported that Salmonella was isolated from two-thirds of Japanese pond turtles for sale in pet shops in Japan ${ }^{21)}$, there have been no case reports of salmonellosis associated with Japanese pond turtles.

Unfortunately, in the present case, pulsed-field gel electrophoresis could not be performed. However, the patient was diagnosed with TAS because Salmonella Litchfield was isolated from his stool and the swab sample of the turtle's body; he had not ingested contaminated foods of animal origin. The infant never touched the turtles, so he could not have contracted Salmonella Litchfield directly from the turtles. It was assumed that he contracted Salmonella Litchfield via his father or the bathroom. His parents were unaware that the turtles may carry Salmonella. Fortunately, the patient responded well to treatment and recovered without complications, despite being at greater risk of developing complications and death due to his age.

In conclusion, Japanese pond turtles can be a sources of salmonellosis, as well as other reptiles. TAS can be prevented through careful hygiene and by limiting the interaction of infants and young children with turtles and their environments.

Conflict of interest: The authors declare no conflict of interest.

\section{References}

1. Walters MS, Simmons L, Anderson TC, et al. Outbreaks of salmonellosis from small turtles. Pediatrics 2016; 137: e20151735. [Medline] [CrossRef]

2. Marin C, Ingresa-Capaccioni S, González-Bodi S, et al. Free-living turtles are a reservoir for Salmonella but not for Campylobacter. PLoS One 2013; 8 : e72350. [Medline] [CrossRef]

3. Bush ER, Baker SE, Macdonald DW. Global trade in exotic pets 2006-2012. Conserv Biol 2014; 28: 663-676. [Medline] [CrossRef]

4. Kuroki T, Ishihara T, Nakajima N, et al. Prevalence of Salmonella enterica subspecies enterica in red-eared sliders Trachemys scripta elegans retailed in 
pet shops in Japan. Jpn J Infect Dis 2019; 72: 38-43. [Medline] [CrossRef]

5. Dekker JP, Frank KM. Salmonella, Shigella, and yersinia. Clin Lab Med 2015; 35: 225-246. [Medline] [CrossRef]

6. Wallace P, Kirk MD, Munnoch SA, et al. An outbreak of Salmonella Litchfield on a car rally, Northern Territory, 2009. Commun Dis Intell Q Rep 2010; 34: 124-126. [Medline]

7. Lafuente S, Bellido JB, Moraga FA, et al. Salmonella paratyphi B and Salmonella litchfield outbreaks associated with pet turtle exposure in Spain. Enferm Infecc Microbiol Clin 2013; 31: 32-35. [Medline] [CrossRef]

8. Gibbs R, Pingault N, Mazzucchelli T, et al. An outbreak of Salmonella enterica serotype Litchfield infection in Australia linked to consumption of contaminated papaya. J Food Prot 2009; 72: 1094-1098. [Medline] [CrossRef]

9. Centers for Disease Control and Prevention (CDC) Salmonella Litchfield outbreak associated with a hotel restaurant-Atlantic City, New Jersey, 2007. MMWR Morb Mortal Wkly Rep 2008; 57: 775-779. [Medline]

10. Hirose M, Hirasawa K, Koguro Y, et al. Survey of pet turtles and their raising water for the contamination with Salmonella. Annual Report of Fukushima Institute of Public Health and Environmental Science 1988; 5: 57-61 (in Japanese)

11. Kibayashi M. A case report of turtle-associated salmonellosis in infancy. Medical Journal Aomori 1992; 37: $288-291$ (in Japanese).

12. Wells EV, Boulton M, Hall W, et al. Reptile-associated salmonellosis in preschool-aged children in Michigan, January 2001-June 2003. Clin Infect Dis 2004; 39: 687-691. [Medline] [CrossRef]

13. Mermin J, Hoar B, Angulo FJ. Iguanas and Salmonella marina infection in children: a reflection of the increasing incidence of reptile-associated salmonellosis in the United States. Pediatrics 1997; 99: 399-402. [Medline] [CrossRef]

14. Cohen ML, Potter M, Pollard R, et al. Turtle-associated salmonellosis in the United States. Effect of public health action, 1970 to 1976. JAMA 1980; 243: 1247-1249. [Medline] [CrossRef]

15. de Jong B, Andersson Y, Ekdahl K. Effect of regulation and education on reptile-associated salmonellosis. Emerg Infect Dis 2005; 11: 398-403. [Medline] [CrossRef]

16. Nakamori J, Miyazaki K, Nishio T, et al. Pet terrapin-linked salmonellosis; first proved cases in Japan and its epidemiology. Rinsho-to-Saikin 1976; 3 : 88-94 (in Japanese).

17. Nagano N, Oana S, Nagano Y, et al. A severe Salmonella enterica serotype Paratyphi B infection in a child related to a pet turtle, Trachemys scripta elegans. Jpn J Infect Dis 2006; 59: 132-134. [Medline]

18. Kuroki T, Ito K, Ishihara T, et al. Turtle-Associated Salmonella Infections in Kanagawa, Japan. Jpn J Infect Dis 2015; 68: 333-337. [Medline] [CrossRef]

19. Kaibu H, Iida K, Ueki S, et al. Salmonellosis of infants presumably originating from an infected turtle in Nagasaki, Japan. Jpn J Infect Dis 2006; 59: 281. [Medline]

20. Ministry of Health, Labour and Welfare of Japan. Handling of reptiles including turtles Q \& A. https://www.mhlw.go.jp/bunya/kenkou/kekkaku-kansenshou19/salmonella_qa.html Accessed April 17, 2021. Renewed in August 2013 (in Japanese).

21. Kameyama M, Yabata J, Tomonaga K, et al. Prevalence of Salmonella species isolated from reptiles sold in pet stores in Yamaguchi Prefecture and their drug susceptibility. Nippon Juishikai Zasshi 2013; 66: 331-336 (in Japanese, Abstract in English). 